\title{
Serological Evidence of PPR Virus in Chadian Camels
}

\author{
Bidjeh Kebkiba ${ }^{1 *}$, Abakar Oumar ${ }^{2}$, Ouagal Mahamat ${ }^{1}$, Tchari Doungous ${ }^{1}$ and Assane Kembé ${ }^{1}$ \\ ${ }^{1}$ Livestock Research Institute for Development (LRID), Chad \\ ${ }^{2}$ Faculty of Exact and Applied Sciences, University of N'Djamena, Chad
}

Submission: March 31, 2019; Published: April 17, 2019

*Corresponding author: Bidjeh Kebkiba, Livestock Research Institute for Development (LRID), Farcha street PO Box. 433, N'Djamena- Chad, Chad

\begin{abstract}
Peste des petits ruminants are an acute fever disease of goats and sheep. It is characterized in these animals by mucopurulent nasal and ocular discharge, erosive and necrotic stomatitis, enteritis and pneumonia. It is widespread, virulent and devastating, with significant impacts on the economy, food security and livelihoods of marginalized pastoralists. This study provides information on the serological prevalence of PPR virus in 510 camel. Most of the samples for this study were obtained at the N'Djamena abattoir. Sera used to detect PPR virus antibodies were not necessarily representative of the target population, although they came from a larger number of provinces. The test used for the analysis of these sera is the competition ELISA (c-ELISA) developed by CIRAD and marketed by IDVET. Examination of the 510 sera collected from camels revealed that the serological prevalence of PPR virus was $25.88 \%$. This seroprevalence of PPR virus varied by province, age group, and geographic area. The study showed a much higher seroprevalence in animals ranging in age from 6 to 10 years than in animals of other age groups. In view of these results, an additional study is to be undertaken on the epidemiological surveillance in the camel population throughout the national territory to detect clinical cases of this disease in camels. In addition, it would be desirable to carry out a serological survey of this disease nationally on random representative sampling in order to find out the true seroprevalence rate of peste des petits ruminants in Chadian dromedaries.
\end{abstract}

Keywords: Serology; c-ELISA; Antibodies; Camels; Viruses; Peste des petits ruminants; Chad

\section{Introduction}

The Republic of Chad is a Sahelian country with a pastoral vocation, it bases its economy largely on the agricultural sector ( $40 \%$ of the national GDP). Chadian livestock contributes $37 \%$ of GDP to the agricultural sector. Apart from the oil sector, it is the largest export contributor, ranging from $30 \%$ to $50 \%$. It supports $40 \%$ of the rural population and employs $80 \%$ of the working population, most of whom are women [1]. According to the last general census of livestock [2], Republic of Chad has about 94 million head of cattle all species including 6.4 million (6.8\%) camelins. The Republic of Chad is one of the Sahelian countries where there is a significant increase in the camel population [3]. These species, very resistant to drought, once concentrated in the Saharan and Sahelian zone of the country. But in recent years, with climate change, they are even found in the Sudanian zone especially during the dry season, in search of pasture and water.

In Chad, the rearing system is $83.33 \%$ transhumant and associative (camels, cattle, sheep and goats). However, certain constraints limit the development of this sector. These include transboundary diseases such as PPR. In fact, PPR is an infectious and contagious disease of domestic or wild small ruminants. It affects domestic or wild small ruminants and camels. Cattle and pigs form a subclinical form of the disease but do not excrete the virus [4]. Buffaloes and pigs may be infected with the virus, but do not show clinical signs [5-7]. PPR is characterized in small ruminants by lacrimation, serous and mucopurulent discharge, oral lesions, diarrhea, pneumonia and often death. In camels, these signs are not clinically visible. This may be why surveillance agents do not report suspicions of the disease in these animals.

According to Roger, Khalafalla [8-10], in camels, PPR is clinically characterized by the sudden death of apparently healthy animals, bloody and yellowish diarrhea, abortion in pregnant females. Decrease in milk production, weight loss and decrease in water consumption sometimes up to 10-14 days. The morbidity rate is $90 \%$ and the mortality varies between 0 and $50 \%$ depending on the environment. The receptivity of camels to the PPR virus has been demonstrated in some African countries such as: Nigeria [11-13], Sudan [14], Libya [15] and Tanzania [16]. In Africa, the disease is recorded in several countries and is an impediment to the development of small ruminant livestock [17]. In Chad, the existence of PPR in small ruminants has been confirmed by serological surveys $[18,19]$ and subsequent isolation of the pathogen [20]. However, in camels no information is available so far. The objective of this study is therefore to detect the antibodies directed against the PPR virus in camels. Due to the lack of financial means, the study focused on camels intended for the slaughterhouse of N'Djamena. 
Material and Methods

\section{Animals}

A total of 510 camels of which 313 females (61.37\%) and 197 males (38.62\%) were sampled. Beforehand, a survey of breeders and traders made it possible to know the origin of the dromedaries. According to the results of this survey, the animals come from Barh El Gazel, Batha, Borkou, Chari-Baguirmi, EnnediWest, Hadjer-Lamis, Kanem, Salamat and Wadi-Fira (Figure 1). The animals sold in the markets of N'Djamena and brought to the slaughterhouse come mostly from the provinces of Batha and Chari Baguirmi.

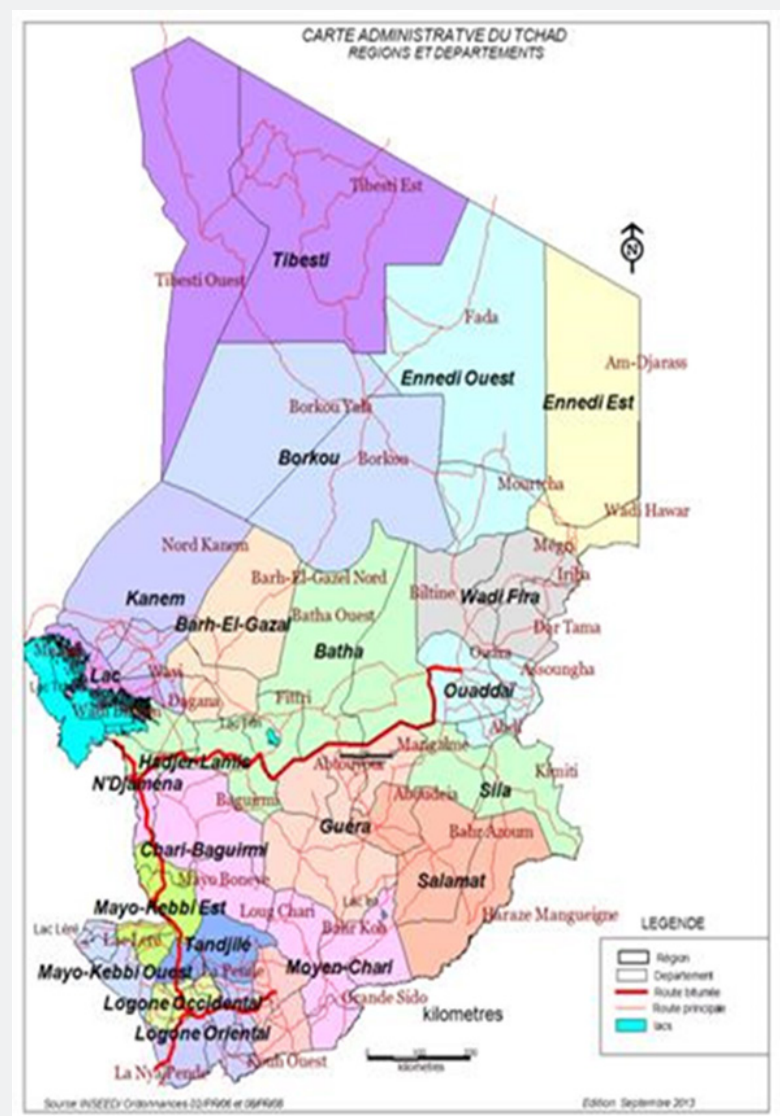

Figure 1: Administrative division of Chad.

\section{Serums}

The samples were taken at the abattoir of Farcha for 2 months (from September 20th to November 20th). The blood is taken from live dromedaries in the jugular vein in venoject dry tubes using a needle mounted on a tube holder. The sampling was done very early in the morning in the slaughterhouse car park before the animals passed on the slaughter line. The tubes filled with blood are then left in the shade for $1 \mathrm{~h} 30 \mathrm{~min}$ for the blood to clot and then transported to the laboratory for the collection of sera. After extraction of the clot, the contents of the tubes are centrifuged at $3000 \mathrm{rpm}$ for $5 \mathrm{~min}$; the supernatant which constitutes the serum is then transferred into cryotubes and stored at $-20^{\circ} \mathrm{C}$. for later use. A total of 406 camel sera were collected at the Farcha cold-storage facility (N'Djamena) and 104 sera collected from camels in the Ennedi West and Wadi-Fira Provinces, giving a total of 510 sera. The information relating to the animal taken is marked on the tubes using an indelible marker and those relating to the animals are also noted on the sheets specially prepared for this purpose.

\section{Serum analysis in the laboratory}

The sera collected are analyzed in the IRED virology laboratory by the competitive ELISA test (c-ELISA) for the detection of antibodies against the PPR virus. The said test was developed by CIRAD / EMVT [21] but marketed by IDvet IDScreen ${ }^{\circledR}$ PPR Competition provided free of charge by the International Atomic Energy Agency (IAEA) as part of a TCPProject \# CHD2015005. The protocol used is that recommended by the manufacturer whose description is as follows:

\section{Description and principle of the c-ELISA test}

The plates were sensitized with the purified recombinant nucleoprotein (NP) of the PPR virus. The samples to be tested and the control sera are diluted to $1 / 2$ and then distributed in the pre-sensitized cups. The anti-NP PPR antibodies, if present in the sera, form an antibody-antigen complex. An anti-NP peroxidase labeled PPR conjugate (po) is then dispensed into the wells. The latter binds to the antigen remained free thereby forming an antigen-antibody-conjugate-po complex. After removing the 
excess of the conjugate by washing, the reaction is revealed by a substrate solution (TMB). The resulting staining is related to the number of specific antibodies present in the samples to be tested.

a. In the absence of specific antibodies in the samples, a blue color appears which then becomes yellow after addition of the stop solution.

b. In the presence of specific antibodies in the samples, no staining appears. The reading is carried out using a PR4100 Bio RAD ELISA reader at a wavelength of $450 \mathrm{~nm}$. The reader is connected to a computer and a printer.

\section{Test Procedure}

Before use, all reagents are brought to a temperature of 21 ${ }^{\circ} \mathrm{C}\left( \pm 5^{\circ} \mathrm{C}\right)$ and then homogenized using the vortex. The different steps of the procedure are as follows:

I. Distribute

a. $25 \mu \mathrm{l}$ of the Dilution Buffer 13 in each well;

b. $\quad 50 \mu$ l Positive control serum in wells A1 and B1;

c. $50 \mu \mathrm{l}$ of diluent 13 used as Negative Control in wells C1 and D1;

d. $50 \mu \mathrm{l}$ of each sample to be tested in the remaining cups.

II. Incubate overnight at $21^{\circ} \mathrm{C}\left( \pm 5^{\circ} \mathrm{C}\right)$

III. Empty the wells and wash them 3 times with $300 \mu$ l of the Wash Solution. At this stage, it is necessary to avoid the drying of the cups between the washing phases.

IV. Prepare the $1 \mathrm{X}$ Conjugate by diluting the $10 \mathrm{X}$ Conjugate $1 / 10$ th in the Dilution Buffer.

V. Empty the wells and wash them 3 times with $300 \mu$ l of the Wash Solution. Avoid drying the cups between the washings.

VI. Add $100 \mu$ l of the Developer Solution to each well.

VII. Incubate at $21^{\circ} \mathrm{C}\left( \pm 5^{\circ} \mathrm{C}\right)$ for $15 \mathrm{~min}( \pm 2) \min$. Protected from light (dark).

VIII. Dispense $100 \mu \mathrm{l}$ Stop Solution into each well to stop the reaction.

IX. Read the 450nm wavelength response from the ELISA reader and record the optical densities (OD) on the computer connected to the reader

\section{Validation of the Test}

The test is validated if:

a. The average value of the negative control optical densities (DOCN) is greater than 0.700. (DOCN>0.700);

b. The mean value of the optical densities of the positive controls (DOCP) is less than $30 \%$ of the DOCN. (DOCP / DOCN $<0.3)$.

\section{Interpretation}

For the calculation of the percentage of the competition (S / $\mathrm{N} \%$ ), the average of the OD obtained in the wells containing diluent 13 is used as a negative control: S / N\% = sample / DOCN x 100. Samples with S / N\% less than or equal to $50 \%$ are considered positive; greater than $50 \%$ and less than or equal to $60 \%$ are considered doubtful and more than $60 \%$ are considered negative (Tables 1-3).

Table 1: Interpretation of the results of the c-ELISA test.

\begin{tabular}{|c|c|}
\hline Résults & Statuts \\
\hline S/N\% $\leq 50 \%$ & Positive \\
\hline $50 \%<$ S/N\% $\leq 60 \%$ & Doubtful \\
\hline S/N\% $>60 \%$ & Negative \\
\hline
\end{tabular}

Table 2: Distribution of sampled dromadaries according to the source.

\begin{tabular}{|c|c|c|}
\hline Variables & Number $(\mathrm{N})$ & Percentage (\%) \\
\hline \multicolumn{3}{|c|}{ Provenance (Province) } \\
\hline Barh El Gazel & 62 & $12,16 \%$ \\
\hline Batha & 125 & $24,51 \%$ \\
\hline Borkou & 11 & $2,16 \%$ \\
\hline Chari-Baguirmi & 89 & $17,45 \%$ \\
\hline Ennedi-Ouest & 75 & $14,71 \%$ \\
\hline Hadjer-Lamis & 22 & $4,31 \%$ \\
\hline Kanem & 87 & $17,06 \%$ \\
\hline Salamat & 10 & $1,96 \%$ \\
\hline Wadi-Fira & 29 & $5,69 \%$ \\
\hline Total & 510 & $100 \%$ \\
\hline
\end{tabular}

Table 3: Distribution of sampled dromedaries by age groups

\begin{tabular}{|c|c|c|}
\hline Age groups & Number $(\mathbf{N})$ & $\mathbf{\%}$ \\
\hline $0-5$ & 123 & 24,11 \\
\hline $6-10$ & 272 & 53,33 \\
\hline $11-15$ & 104 & 20,39 \\
\hline $16-20$ & 11 & 2,15 \\
\hline Total & 510 & 100 \\
\hline
\end{tabular}

\section{Statistical Analysis}

All collected data and serum analysis results were entered into a relational database designed on Access. The Excel 2010, $\mathrm{R}$ and Quantum GIS software's, my practical online mediatory, were used for the statistical analysis of the data.

Results

The sample size is 510 camels of which 313 females are $61.37 \%$ and 197 males are $38.63 \%$ (Table 4). The animals sold in the markets of N'Djamena and brought to the slaughterhouse come for the most part from the provinces of Batha and Chari Baguirmi $24.51 \%$ and $17,45 \%$ respectively. Of the dromedaries sampled, 272 (53.33\%) are aged between 6 and 10 years; 123 (24.12\%) aged 0-5 years; 104 (20.39\%) aged 11 and 15 and 11 
(2.16\%) aged between 16 and 20 years (Table 3). Regarding the serological results, out of the 510 sera tested, 132 or $25,88 \%$

were positive vis-à-vis the PPR virus and 378 (74.12\%) negative (Figure 2).

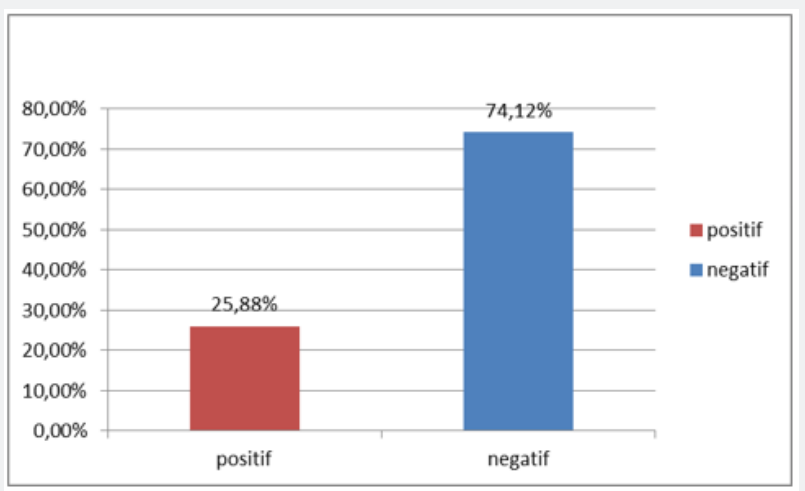

Figure 2: Overall seroprevalence rate.

Table 4: Distribution of camels sampled by sex.

\begin{tabular}{|c|c|c|}
\hline Sex & Number (N) & \% \\
\hline Males & 197 & 38,63 \\
\hline Femelles & 313 & 61,37 \\
\hline Total & 510 & 100 \\
\hline
\end{tabular}

Table 5: Seroprevalence rate of PPR in camels by different provinces.

\begin{tabular}{|c|c|c|c|c|}
\hline \multirow[t]{2}{*}{ Provenance (Province) } & \multicolumn{2}{|c|}{ Résult } & \multirow[t]{2}{*}{$\mathbf{N}$} & \multirow[t]{2}{*}{ IC $95 \%$} \\
\hline & Positive (\%) & Négative (\%) & & \\
\hline Barh El Gazel & $19(30,65 \%)$ & $43(69,35 \%)$ & 62 & {$[19,2 ; 42,1]$} \\
\hline Batha & $35(28,00 \%)$ & $90(72,00 \%)$ & 125 & {$[20,1 ; 35,9]$} \\
\hline Borkou & $0(00,00 \%)$ & $11(100 \%)$ & 11 & {$[00,0 ; 00,0]$} \\
\hline Chari-Baguirmi & $35(39,33 \%)$ & $54(60,67 \%)$ & 89 & {$[29,2 ; 49,5]$} \\
\hline Ennedi-Ouest & $14(18,67 \%)$ & $61(81,33 \%)$ & 75 & {$[09,9 ; 27,5]$} \\
\hline Hadjer-Lamis & $5(22,73 \%)$ & $17(77,27 \%)$ & 22 & {$[05,2 ; 40,2]$} \\
\hline Kanem & $23(26,44 \%)$ & $64(73,56 \%)$ & 87 & {$[17,2 ; 35,7]$} \\
\hline Salamat & $0(00,00 \%)$ & $10(100 \%)$ & 10 & {$[00,0 ; 00,0]$} \\
\hline Wadi-Fira & $1(3,45 \%)$ & $28(96,55 \%)$ & 29 & {$[-3,2 ; 10,1]$} \\
\hline Total & $132(25,88 \%)$ & $378(74,12 \%)$ & $510(100 \%)$ & {$[22,1 ; 29,7]$} \\
\hline
\end{tabular}

Table 4 presents the seroprevalence rate of PPR in the is relatively higher in males (29.44\%) than in females (23.64\%). different provinces. Of the 9 provinces surveyed, seven (7) are affected by PPR against two (2) provinces with a seroprevalence rate of $0 \%$. The province where the seroprevalence rate is higher is Chari-Baguirmi (39.33\%), followed by Barh El Gazel Province $(30.65 \%)$. On the other hand, the lowest seroprevalence rate is observed in the provinces of Borkou, Salamat $(00.00 \%)$ and Wadi-Fira (3.45\%). Table 5 shows the seroprevalence rate by sex. From this table it can be noted that the seroprevalence rate Table 6 shows seroprevalence rate in camels as a function of age. From this table it can be noted that the highest seroprevalence rate $(27.57 \%)$ is obtained in camels whose age is between 6 and 10 years. In animals aged between 0 and 5 years, the seroprevalence rate is $26.83 \%$. The lowest seroprevalence rate is recorded in animals aged between 16 and 20 years (18.18\%) (Table 7).

Table 6: Seroprevalence rate of PPR by sex.

\begin{tabular}{|c|c|c|c|c|}
\hline Sex & \multicolumn{2}{|c|}{ Résult } & N & IC \\
\hline & Positive & Négative & 313 & {$[18,9 \% ; 28,3 \%]$} \\
\hline Female & $74(23,64 \%)$ & $239(76,36 \%)$ & 197 & {$[23,1 \% ; 35,8 \%]$} \\
\hline Mâle & $58(29,44 \%)$ & $139(70,56 \%)$ & $510(100 \%)$ & {$[22,1 \% ; 29,7 \%]$} \\
\hline Total & $132(25,88 \%)$ & $378(74,12 \%)$ & & \\
\hline
\end{tabular}


Journal of Dairy \& Veterinary Sciences

Table 7: Seroprevalence rate of PPR by age groups.

\begin{tabular}{|c|c|c|c|c|}
\hline \multirow[t]{2}{*}{ Age (ans) } & \multicolumn{2}{|c|}{ Résultat } & \multirow[t]{2}{*}{$\mathbf{N}$} & \multirow[t]{2}{*}{ IC } \\
\hline & Positive (\%) & Négative (\%) & & \\
\hline 0 à 5 & $33(26,83 \%)$ & $90(73,17 \%)$ & 123 & [19\% ; 34,7 \%] \\
\hline 6 à 10 & $75(27,57 \%)$ & $197(72,43 \%)$ & 272 & {$[22,3 \% ; 32,9 \%]$} \\
\hline 11 à 15 & $22(21,15 \%)$ & $82(78,85 \%)$ & 104 & {$[13,3 \% ; 29 \%]$} \\
\hline 16 à 20 & $2(18,18 \%)$ & $9(81,82 \%)$ & 11 & {$[-4,6 \% ; 41 \%]$} \\
\hline Total & $132(25,88 \%)$ & $378(74,12 \%)$ & $510(100 \%)$ & {$[22,1 \% ; 29,7 \%]$} \\
\hline
\end{tabular}

\section{Discussion}

PPR is one of the most serious viral infections affecting domestic and wild small ruminants, as well as camels, with increasing incidence and geographical distribution. Despite a very important socio-economic impact, this disease has received little public attention since its discovery, and this has to a large extent led to its wide dissemination. Since 1992, camels are suspected to be possible hosts of the PPR virus. Serological surveys conducted in different countries, Sudan, Egypt, Libya revealed their seropositivity but without clinical manifestation of the disease and isolation of the virus. The seroprevalence rate of $25.88 \%$ obtained in this study confirms the circulation of the PPR virus in the Chadian camel population. The study showed a higher prevalence rate in males than in females. These results are different from those obtained by Swai [16] in Tanzania, showing a seroprevalence rate of $2.7 \%$ in females and $2.0 \%$ in males, but are similar to those obtained by Woma [13] in Nigeria.

Although the seroprevalence of PPR is known in small ruminants in Chad [18-19,22-23], this study showed for the first time a Seroprevalence of PPR in Chadian dromedaries. The anti-PPR antibodies observed in this study could only come from a natural infection, as there is no documented evidence that camels were vaccinated against PPR Virus in Chad. Camels are believed to be responsible for the spread of the PPR virus. The serological results obtained in this study are superior to those obtained by Ismail [24] in Egypt (4.2\%), Daneji [11] in Nigeria (4\%), Roger [9] in Ethiopia (7.8\%) and Swai [16] in Tanzania (2.6\%). Chari-Baguirmi is the province with the highest seroprevalence rate $(39.33 \%)$. This Province is a meeting point for transhumant animals. It should also be noted that this region is the area where there has been more suspicion of PPR in small ruminants [22]. The low rates of seroprevalence obtained in the Provinces of Wadi-Fira, Borkou and Salamat can be explained by the low number of serums taken since few camels sold on the markets of N'Djamena are those coming from these Provinces. The study showed a slightly higher prevalence rate in males than in females. These results are different from those obtained by Swai [16] in Tanzania, showing a seroprevalence rate of $2.7 \%$ in males and $2.0 \%$ in females, but are similar to those obtained by Woma [13] in Nigeria.
The seroprevalence rate is higher in animals between 6 and 10 years of age than in other age groups. A low rate of seroprevalence is observed in camels whose age varies between 16 and 20 years. These results are similar to those obtained in Nigeria [13] and in Tanzania where the seroprevalence rate among camels aged between 5 and 10 is high compared to other age groups [16].

\section{Conclusion}

Although clinical cases of PPR were not observed in the field, the results of this study showed a PPR seroprevalence rate of $25.88 \%$ in Chadian dromedaries, which confirms the receptivity of these animals to PPR virus. In view of the results obtained, further research should be considered in order to clarify the role of dromedaries in the epidemiology of the PPR virus in Chad. However, special attention should be paid to this species in the strategy of control and eradication of peste des petits ruminants. Also, an additional study is to be undertaken on the epidemiological surveillance in the camel population throughout the national territory to detect clinical cases of this disease in camels. In addition, it would be desirable to carry out a serological survey of this disease nationally on random representative sampling in order to find out the true seroprevalence rate of peste des petits ruminants in Chadian dromedaries. In order to demonstrate the real role of camels in the spread of the PPR virus, an experimental reproduction study of this disease in small ruminants and dromedaries in the resort is necessary.

\section{Acknowledgements}

The authors sincerely thank the International Atomic Energy Agency (IAEA) for providing the ELISA-PPR Kit free of charge. Our thanks also go to all those who, from near or far, contributed to the realization of this study.

\section{Conflict of Interest}

There is no conflict of interest

\section{References}

1. National Livestock Development Plan (PNDE) (2009) Ministry of Livestock and Animal Resources p. 82. 
2. General Census of Livestock (RGE) (2015) Ministry of Livestock and Animal Productions. Annual Statistical Report p. 55.

3. Faye Gilles Vias-Franck, Mahmadou Chaibou (2013) Does dromedary benefit from climate change? Environment letter of INRA 63: 131-140.

4. Shaila MS, Shamaki D, Morag A Forsyth, Adama Diallo, Lynnette Goatley RP, et al. (1996) Geographic distribution and epidemiology of peste des petits ruminants viruses. Virus Research 43(2): 149-153.

5. Abu-Elzein EME, Housawi FMT, Bashareek Y, Gameel AA, Al-Afaleq $A L$, et al. (2004) Severe PPR infection in gazelles kept under semi-free range conditions. J. Vet. Med. B. Infect. Dis. Vet. Public Health 51: 68-71.

6. World Organization for Animal Health (OIE) (2002) Peste des petits ruminants. Animal disease data.

7. Furley CW, Taylor WP, Obi TU (1987) An outbreak of peste des petits ruminants in a zoological collection. Vet Rec 121: 443-447.

8. Roger F, Yigezu M, Hurard C, Libeau G, Mebratu GY, et al. (2000) Investigations on a new pathological condition of camels in Ethiopia. JCPR 7(2) : 163-165.

9. Roger F, Guebre Yesus M, Libeau G, Diallo Yigezu LM, Yilma T (2001) Detection of antibodies of rinderpest and peste des petits ruminants viruses (Paramyxoviridae, Morbillivirus) during a new epizootic disease in Ethiopian camels (Camelus dromedarius). Rev Med Vet 152 265-268.

10. Khalafalla AI, Intisar KS, Yahia HA, Magdi BA, Kwiatek O, et al. (2010) An outbreak of peste des petits ruminants (PPR) in camels in the Sudan. Acta Tropica $116: 161-165$

11. Daneji AI, Chafe UM, Tahir FA (1997) Antibody to peste des petits ruminants virus (PPRV) in donkeys and camels in Sokoto State, Nigeria. In the proceedings of the Annual Conference of the Nigerian Veterinary Medical Association p. 92-93.

12. Abubakar MB, Sanda AB, El-Yuguda AD, Baba SS (2008) Seroprevalence of Morbillivirus antibody and abattoir survey of one humped slaughtered camels (Camelus dromedarius) in Maiduguri Municipal Abattoir Maiduguri, Nigeria. Asian Journal of Scientific Research 1(1) 85-89.

13. Woma YT, Melvyn Q, Bailey D, JU Kalla D, Ularamu HG, et al. (2015) Séroprevalence of peste des petits ruminants Nigerian camels. empresanimal health.
14. Saeed IK, Ali YH, Khalafalla AI, Rahman- Mahasin EA (2010) Current situation of Peste des petits ruminants (PPR) in the Sudan. Tropical Animal Health and Production 42(1): 89-93.

15. El-Dakhly AT (2015) Serological Survey for Peste Des Petits Ruminants Virus (PPRv) in Camel from Different Regions in the West of Libya. International Journal of Science and Research, pp. 2319-7064.

16. Swai ES, Moshy W, Mbise E, Kaaya J, Bwanga S (2011) Serological evidence of camel exposure to Peste des Petits ruminants virus in Tanzania. Research Opinions in Animal \& Veterinary Sciences 1(5) : 325-329.

17. Diallo A, Minet C, Le Goff C, Berhe G, Albina E, etal. (2007) The threat of peste des petits ruminants: progress in vaccine development for disease control. Vaccine 25: 5591-5597.

18. Provost A (1973) Peste des petits ruminants. Farcha, Chad, Veterinary and zootechnical research laboratory of Farcha. (Annual report) 106: 108-118.

19. Bidjeh K, Idriss AO, Diguimbaye C, Ganda K, Maurice Y (1989) Incidence of rinderpest antibodies in small ruminants in Chad. Bull Rech Appl (CRA) 5: 31-36

20. Bidjeh K, Bornarel P, Imadine M, Lancelot R (1995) First isolation in Chad of PPR virus and experimental reproduction of the disease. Rev. Med. Vet. Country 48(4): 295-300.

21. Libeau G, Prehaud C, Lancelot R, Colas F, Guerre L, et al. (1994) Development of a competitive ELISA for detecting antibodies to the peste des petits ruminants virus using a recombinant nucleoprotein. Res Vet Sci 58(1): 50-55.

22. Bidjeh K, Ban-bo BA, Fayiz AM, Assandi O, Assane K, et al. (2015) Distribution and Seroprevalence of PPR Virus in Chad During 2004 2014. Animal and Veterinary Sciences 3(3) : 89-93.

23. Lancelot R, Imadine M, Mopate Y, Faye B (1993) The Ecopathological Investigation on Goat Pneumopathies In the cold dry season In Chad: Methodological Aspects. Rev Elev Med Vet Country Too 46(3): 485-494

24. Ismail TM, Hassan HB, Nawal MA, Youssef Rakha GM, El-Halim MMA et al. (1992) Studies on prevalence of rinderpest and peste des petits ruminants antibodies in camel sera in Egypt. Vet Med J Giza 10(2) : 49-53.
This work is licensed under Creative Commons Attribution 4.0 License DOI: 10.19080/JDVS.2019.11.555809

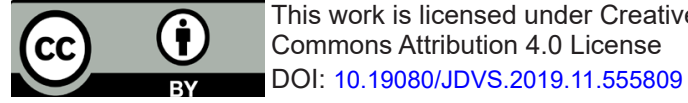

\section{Your next submission with Juniper Publishers}

\section{will reach you the below assets}

- Quality Editorial service

- Swift Peer Review

- Reprints availability

- E-prints Service

- Manuscript Podcast for convenient understanding

- Global attainment for your research

- Manuscript accessibility in different formats

( Pdf, E-pub, Full Text, Audio)

- Unceasing customer service

Track the below URL for one-step submission https://juniperpublishers.com/online-submission.php 